\title{
Body and Social Interaction-The Case of Dance. Symbolic Interactionist Perspective
}

\author{
Dominika Byczkowska-Owczarek \\ University of Lodz, Poland
}

DOI: http://dx.doi.org/10.18778/1733-8077.16.4.10

\section{Keywords:}

Symbolic

Interactionism; Body;

Interaction; Sociology

in Poland; Grounded

Theory Methodology;

Dance; Identity

\begin{abstract}
The article aims at presenting the symbolic interactionism as a useful and flexible theoretical perspective in research on the human body. It shows the assumptions of symbolic interactionism in their relation to the human body, as well as explains how basic notions of this theoretical perspective are embodied-the self, social role, identity, acting, interacting. I depict the unobvious presence of the body in the classical works of George H. Mead, Anselm Strauss, Howard Becker, Erving Goffman, and in more recent ones, such as Bryan Turner, Ken Plummer, and Loïc Wacquant. I also describe the Polish contribution to the field, including research on disability, hand transplant, the identity of a disabled person, together with the influence of sport, prostitution as work, yoga, climbing, relationships between animals and humans based on gestures and bodily conduct, the socialization of young actors and actresses, non-heteronormative motherhood, and the socialization of children in sport and dance. In a case study based on the research on ballroom dancers, I show how to relate the theoretical requirements of symbolic interactionism with real human "flesh and bones." I depict three ways of perceiving own bodies by dancers: a material, a tool, a partner; and, two processes their bodies are subjected to: sharpening and polishing a tool. I draw the link between the processual character of the body, of the symbolic interactionist theoretical perspective, and process-focused grounded theory methodology.
\end{abstract}

Dominika Byczkowska-Owczarek, sociologist, is an Assistant Professor in the Department of Sociology of Culture, Faculty of Economics and Sociology at the University of Lodz, Poland. Her book, Body in Dance. Sociological Analysis, presents the outcomes of a study on ballroom dancing as a social activity. She has participated in research projects concerning communication on hospital wards, lobbying, revitalization of cities, and HR proce- dures. She is a book review editor in the Qualitative Sociology Review and Przeglad Socjologii Jakościowej. Her main scientific interests are: symbolic interactionism, grounded theory methodology, qualitative methods, autoethnography, sociology of the body, sociology of medicine, ethnographic research.

email address: byczkowska.owczarek@uni.lodz.pl 
...objects have the meanings and are acted toward. Among these objects are the body, certain of its parts, and possibly some of its physiological systems.

[Strauss 1993:111]

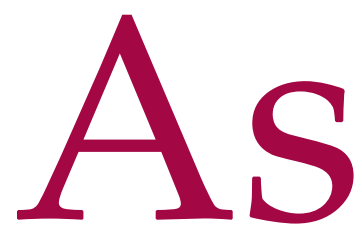

Anselm Strauss claims, "Concerning bodies, and their biological connotations, there are ghosts that haunt the social sciences" (1993:107). Until the social and cultural changes of the last thirty years, the interest in the human body was manifested primarily by biological and medical sciences. The transformations caused by the feminist movement, development of medicine, globalization, and increasing migration have altered the way social scientists approach human corporeality. The meaning of the human body, its appearance, functions, and the influence it has on others have recently gained in importance. Due to cultural changes in the modern world, the body is no longer a mere physical entity, an instrument of the soul, as Descartes claimed. It is a life project, an individual construct, one of the elements of a modern individual's life. As various social institutions, such as family, marriage, local and religious communities, or work, had undergone multiple changes and no longer stand for foreseeable determinants of one's social status, the body seems to be one of the most predictable elements of life.

The research on social and cultural influence on the human body is developing in sociology, anthropology, philosophy, pedagogics, and psychology. The literature on the subject offers numerous examples of studies in the field. However, most of them focus on narratives and the influence that macro-social phenomena, such as marketing, fashion, food, the medical industry, have on the human body. Such phenomena are thought-provoking, as they influence big groups of people, and sometimes shape corporate marketing strategies, health policies, or cause global problems, such as the obesity pandemic. The quantitative studies on the issues at hand are necessary and may help to understand and influence the macro-social processes. However, it may be beneficial to have a closer look on a micro-level and recognize the processes that affect individual actions to understand the specificity of the human body. The macro-social phenomena always constitute a mix of people's experiences, decisions, acts, and identities.

This article aims at proposing symbolic interactionism (SI) as a useful and flexible theoretical perspective, which may help recognize various social aspects of the human body as experienced, managed, and utilized by an individual. The characteristics are perceived as influenced by social and cultural processes through interacting, role-making, negotiating, constructing identity. In the subsequent paragraphs, I depict how the assumptions of SI refer to interest in the human body. Additionally, I present some classical works in the field and shed light on the Polish contribution to the SI research on the human body. In the next part of the text, I present original findings based on my SI study of the human body in dance. The presentation of the research serves as an example of how the SI perspective helps to explain how social interactions have an impact on the human body. I describe the process of the social construction of embodiment: its influence on identities, role-making, the way social actors use their bodies as tools of social interaction. In this part of the text, I will shortly discuss the assumptions of SI. I do not describe them in extension, as I aim to show their relation to the human body and its social aspects. 
SI is a theoretical perspective, according to which society, reality, and the self are created through interactions and based on communication. The leading assertion of this orientation is the processual character of social reality, as a result of its permanent creation by social actors in the process of interpreting the actions of others. Society is a continuously produced and reproduced effect of joint human actions (Blumer 2007).

The first assumption of SI is that people do not react automatically to stimuli, but act consciously towards objects based on the meanings these objects (situations, other people, own and other's bodies) have for them (Charmaz 2006:7; 2014). Everything can become an object of interpretation, also intangible and imagined phenomena. Therefore, the significance of objects to which individuals operate should occupy a central place in the analysis and understanding of social phenomena (Blumer 2007). The body, like any other object, is not "given"; the individual provides its meanings, just like in the case of other objects. The difference is that it is an object of particular importance because we are unable to get rid of it, or distance ourselves from it, as it is always present. Through our bodies, we interact with others, and we also perceive them from the perspective of their corporeality. It is significant for research concerning the human body, as the issues of perceiving one's body have a fundamental meaning for understanding their activities (see also: Denzin 1972:77).

Secondly, the meanings of objects derive from social interactions. The way others act towards a particular subject, for example, their own body or other bodies, is crucial because it results in how one defines a given object (Blumer 2007). People are conscious individuals whose actions depend on their inner conversations (e.g., with imagined significant others). The questions and answers depend on a reference group that sets the fundamental cognitive perspective from which an individual assesses themselves and others. Namely, the way we perceive, treat, use our bodies relies on the way significant others and our reference group treat them. We learn it during primary and secondary socialization and see our bodies through the eyes of others.

Thirdly, people employ meanings and modify them through interpretation. Therefore, the meanings of objects are never explicitly determined, but always recognized and subjected to modifications during the interpretation process. That is why the most fundamental and only "real" phenomenon observable for the researcher is the activity of an individual. Social norms work through actions, which is possible only through the body. Humans change the way they see their bodies depending on how they look, how they act, and whether their capabilities are growing or diminishing.

$$
* * *
$$

The body has been implicitly present in sociology. Some researchers claim that it has always been one of its main categories. As Dennis Vaskul and Phillip Vannini state (2006:13), after Chris Shilling, the body had a specific status of "absent presence" in the history of sociology. It was there in reflections on race, gender, illness, death and dying, disability, sport, aging, or ethnicity (Strauss 1993:108). At the same time, human actions were rarely perceived as embodied, and until lately, the experience of one's body was seldom studied within symbolic interactionist tradition. The body appears in various 
contexts in the classical works by Anselm Strauss, Howard Becker, or Erving Goffman. Still, it explicitly takes on meaning, and its significance for the social activity of an individual becomes visible. However, each of the authors captures the human body differently, from a different standpoint. Moreover, this is in line with the symbolic interactionist perspective on the human body-multithreaded, ambiguous, diverse, just like the operation and people's experiences of their bodies. That is why it is hard to find common ground, or even a shared definition, in symbolic interactionist reflections on the body.

The works of George Herbert Mead, one of the "founding fathers" of SI, serve as an excellent example of the ambiguous presence of the human body as a part of social reality in the sociological gaze. Paradoxically, it was initially absent from his works (see: Konecki 2005). Mead marginalized the importance of the body in social interaction, and thus in the construction of the self. In his view, the self results from the existence of the mind, being underpinned by a conversation with oneself. It points to the importance of using language. However, he seems to ignore non-verbal communication and the meanings it conveys, although it also affects the individual and their interactional partners. The ability to transmit and receive non-verbal signals (through the body) is a necessary condition for interpretation and an inseparable element of this process.

Furthermore, Mead omits the importance of bodily feeling in self-construction. Numerous examples confirming the significant role of the body in building the self also manifest in verbalized experiences of dancers or athletes whose self-identity completely collapsed after a severe injury or due to aging (Rambo Ronai 1992; Turner and Wainwright 2003; Wainwright and Turner 2004). Changing the perspective on your own body is an element that has a significant impact on the transformation of the self. The human body is the primary medium of existence in the world-people interact with each other through their bodies; the body is also a means of defining the situation and interpreting meanings (e.g., emotions).

Classical work introducing the issue of embodiment into the practice of symbolic interaction research date back to 1953, when Howard Becker published "Becoming a Marihuana User." In the article, Becker analyzes how an individual learns to use their body and learns to recognize the sensations of the body influenced by marihuana usage. It is one of the first sociological attempts to offer what may be called a social perspective, in contrast to the biological and objective perception of the human body. The body, in Becker's view, is a tool that needs to be mastered to experience the effects of the drug. An individual must interpret bodily experiences in a proper, socially constructed manner. The adoption of this manner is decisive in whether the individual will become a marihuana user. However, bodily practices, and the body itself, are presented implicitly in the text. Other important classical symbolic interactionist works by Anselm Strauss and associates (e.g., Becker et al. 1961; Glaser and Strauss 1965; Strauss 1993; Strauss et al. 1997) include reflections on illness, the ill body, and illness trajectory. They shed light on the situatedness and social construction of illness, the social role of an ill person. However, just as in Becker's work, the body itself is present only implicitly, as an internal context that shapes the situation of the ill person and their relationships with the family and medical staff. 
In Continual Permutations of Action, a classical book by Anselm Strauss (1993), one may find an explicit reflection on the importance of the human body. The first of Strauss's (1993:23) assumptions concerning action and interaction is that no action is possible without the body. He challenges the implicit division between mind and body, which prevails in philosophy, but also in Western culture since the popularization of Descartes' work. ${ }^{1}$ Strauss claims that although the body is a necessary condition for every action, its notion variesit is "multifaceted," as he terms it. It includes understanding the body as a subject, but also as an object providing complex bodily practices. Such a perspective entails a specific, sociological way of perceiving the human body by symbolic interactionists -in terms of bodily aspects of interactions and relations. As Strauss (1993:24) writes, "The body processes include protecting the body, abusing the body, training the body, shaping the body, presenting the body, symbolizing the body." Due to the diversity and complexity of the body-interaction relationship, his main concern was its adequate conceptualization in social research (Strauss 1993:108). In his opinion, our primary focus should be on action and interaction through the body. As he states (Strauss and Corbin 1988:53-54 as cited in Strauss 1993:109), "communication entails cooperative activity with others...giving meaning to what one feels, one hears, smells and touches."

The managing of the body surfaces in the work of another classical symbolic interactionist, Erving Goffman. He introduced the perspective of bodily aspects of human interaction. In his reflections on

${ }^{1}$ The idea of the soul as separate from the human body dates back to ancient times. Claudius Galenus, a Greek physician, philosopher, and surgeon, claimed that the human soul was in the heart and the brain. stigma, gender advertisements, the face, and bodily work, the body appears as a primary aspect of human existence. As he states in Interaction Ritual: Essays in Face to Face Behavior, "[a] body is subject to falls, hits, poisons, cuts, shots, crushing, drowning, burning, disease, suffocation, and electrocution. A body is a piece of consequential equipment, and its owner is always putting it on the line" (Goffman 2005:167). The body, especially gestures and facial expressions, has a crucial meaning for the course of an interaction. In Goffman's work, also identity is inscribed in the human body, as in cases of gender (1979) or stigma (1963). In his works, vital sociological issues, such as identity, role-making, gender representation, and status, were all embodied and reproduced through interactions, including active body management, as we understand them nowexplicitly.

In 1984, Bryan Turner published The Body and Society: Explorations in Social Theory-a cornerstone of the sociology of the body. Although he does not often refer to social interactions, Turner has made the human body a fully-fledged area of sociological interest.

Another classical work that focused the attention of the general sociological public on the human body was Loïc Wacquant's (2004) Body and Soul. Notes of an Apprentice Boxer (2004). The book offers a unique ethnographic description of the specific cultural and social contexts in which boxing was popularized as a bodily practice that constructed an individual's bodily capital. What Wacquant shows is the importance of becoming a boxer, the construction of a new identity through bodily practice. The great value of the book is its author's own boxing experience, which led him through the process of becoming a boxer in the most physical way. 
The next symbolic interactionist who also referred to his own experience in sociological research on the human body, namely, illness, is Ken Plummer. In his article entitled "My Multiple Sick Bodies: Symbolic Interactionism, Autoethnography, and Embodiment" (Plummer 2012), he presents his various incorporated identities, as well as the unique experience of a liver transplant. The importance of this work lies in its first-hand perspective and the author's dedication to research during his illness. What Plummer also does is an explicit declaration of the limits of sociological research on the human body. His example is pain-a phenomenon impossible to convey by words. Additionally, intense pain is impossible to remember. Therefore, it cannot become an object of analysis. ${ }^{2}$

As mentioned earlier, the issue of the body in international sociology has been present for the last decades, at first, implicitly, and later-explicitly. In the past few years, the same goes for Polish sociology, where the interest in the body increases. It is visible in the growing number of publications on different aspects of the body/embodiment (e.g., Byczkowska-Owczarek 2018), as well as conferences and theses (Jakubowska 2012). The analysis reveals that the majority of Polish sociological investigation is still more focused on theoretical aspects and discourses of the body than on human actions that concern embodiment.

On the one hand, there is a significant number of quantitative studies on physical appearance or

\footnotetext{
${ }^{2}$ Due to the limited length of this work, I have included only a few researchers who, in my opinion, have had the most significant influence on the development of the symbolic interactionist perception of the human body. However, Body/Embodiment: Symbolic Interaction and the Sociology of the Body, edited by Dennis Vaskul and Phillip Vannini (2006), presents the issues at hand broadly and profoundly.
}

physical activity (like fitness or sport), but, on the other hand, the number of qualitative studies, also those embedded in SI tradition, is growing. The research topics refer to various aspects of human bodily activity. One of them is a broad topic of disability, including research on the hand transplant process and its effects on the social life and identity of a patient, conducted by Katarzyna Kowal (2012), and studies on constructing the identity of a disabled person, as influenced by practicing sport, by Jakub Niedbalski (2015). Izabela Ślęzak and Magdalena Wojciechowska researched female prostitution understood as work, depicting such a phenomenon in the context of social identity changes, bodily practices, and role making (Ślęzak 2012; 2018; Wojciechowska 2015a). Krzysztof Konecki, being a practitioner himself, conducted a study on yoga as a bodily practice engaging the soul and emotions (Konecki 2016). A similar situation took place in the case of Anna Kacperczyk's research on climbing as a unique communication between the human body and the work of nature set in the context of a particular social world (Kacperczyk 2016). Another topic of Polish symbolic interactionist research on the human body refers to the relationships between animals and humans, as concluded based on gestures and bodily conduct (Konecki 2008). They offer a comprehensive analysis of interspecies interactions in the social world of pet owners. Also, there was a multiyear study on parenthood among non-heteronormative, mainly lesbian, couples, whose bodily aspect of motherhood is socially created (Wojciechowska 2015b; 2020).

Additionally, symbolic interactionist research on the human body undertakes the issue of socialization of young actors and actresses within the context of various processes of social control, which 
focus on appearance (Dwojnych and Kuczkowska-Golińska 2018). The issue of socialization was also studied in the case of children in sports (Jakubowska and Byczkowska-Owczarek 2018), as well as in dance (Byczkowska 2009; 2012). The last research project will be discussed in the following sections of the article. It is presented as an example of the SI study of the body.

\section{The Body and Dance-An Example of the SI Research on the Body}

In the following part of the text, I will present one of my studies concerning the social construction of the human body. Showing how theoretical assumptions of SI "work" in specific research may be helpful, especially for younger researchers. The theoretical perspective may shape the research when we apply a methodology based on similar foundations. That is why the methodological framework for the study was the grounded theory methodology. Like in the case of SI, this methodological perspective focuses on the dynamic, processual quality of social reality and the crucial meaning of interactions in constructing everyday human actions (Konecki 2000:33-36; Oktay 2012:1213; Charmaz 2014: chapter 10). Grounded theory methodology seems to be fit when it comes to research on the social influence on the human body since its procedures are flexible yet require methodological discipline.

In the study, I applied qualitative data gathering techniques. They included semi-structured interviews, photo and video elicited interviews, autoethnography, observations, and the analysis of photographs, films, and other existing data (e.g., a radio broadcast, an autobiography of a ballet dancer, official regulations). As a social phenom- enon, the human body is not entirely intersubjectively communicable. Therefore, it is methodologically recommended to apply various research techniques, including those operating with data other than the participants' narratives (Byczkowska 2009). During the analysis, the data are coded, allowing the derivation of categories. The researcher returns to the field, where they may find the data, and looks for new information based on the initial analysis and theoretical questions, arising until the saturation of categories is reached. At such a stage, no new proprieties of categories emerge, and we may thus define and develop them (Glaser and Strauss 1967; Glaser 1978; Strauss 1987; Strauss and Corbin 1990; Charmaz 2006; Corbin and Strauss 2007).

\section{The Body and Ballroom Dance}

The research concerned the social subworld ${ }^{3}$ of ballroom dancing in Poland and lasted six years. The theoretical background was the social worlds theory (Strauss 1978; 1982; Clarke 1990), Maurice Merleau-Ponty's phenomenological perspective (1965), the dramaturgical perspective (Goffman 1959), and the concept of dreamwork (Nelson 2001). The analyzed data led me to construct an ethnographical description of the social subworld of ballroom dancing. Additionally, I proposed a concept of the social construction of the human body. It depicts how social phenomena, such as institutionalization, career constructing, adapting a dancer's body to the requirements of the social world, non-verbal embodied communication, the spatial aspects of dance, the socialization of children in ballroom

\footnotetext{
${ }^{3}$ The concept of the social world refers to certain social entities whose boundaries are determined by effective communication, discourse, constant interactions between its members, as well as their reactions to each other (Strauss 1978; 1982; Clarke 1990:18-19; Kacperczyk 2005:169-170).
} 
dancing, influence the human body in a physical manner (Byczkowska 2009; 2012). Some of the outcomes referring, in particular, to symbolic interactions, will be presented below.

The cultural context of actions and interactions in the social subworld of ballroom dancing requires a short introduction. The omnipresent and reproduced formalization and institutionalization of this culture are its most significant aspects. Unification and codification include dance steps, rules, figures, and, subsequently, shoes and gowns. Consequently, they determine the specific character of bodily movements in ballroom dancing, as well as the dancers' career paths. ${ }^{4}$ Dancers train in couples, so sometimes a dancer has the same dancing partner for several years. They participate in competitions and receive one score as a couple. To progress to a subsequent class, a couple must collect several first, second, and third places in dance contests. Therefore, participating in dance contests is the main activity of dancers who subordinate other actions (like training sessions, choice of trainer, private life, etc.) to it-the meaning of rivalry and determination to win increases over time. A "skating system" of complying scores, where there can be no ties, influences some of the dancers' controversial actions, such as catching the judges' attention with seductive glances and performing figures which are formally forbidden at the particular dance level.

Such a kind of culture creates a context for the actions of dancers, whose main activity is focused

\footnotetext{
${ }_{4}^{4}$ The course is formally specified: every dancer must pass through levels, from the lowest level-E-to the highest-A, and later, the international level-S. A dancer starts without any level ascribed, and by participating in training sessions, they learn the dances which are next performed in dance contests and judged.
}

on the strategic development of their career. Their interactions are also subordinated to those particular actions. Situations such as ending the cooperation with a many-years' dancing partner or trainer over the phone, or focusing on the partner's "objective" features exemplifying their potential effectiveness (a financial situation, career plans, or physical abilities) instead of liking them, are regular practices in this social subworld. This type of social context is reproduced by all the actors involved, as all of them interpret ballroom dancing as a competitive action. The dance is not the most important-winning is. Having such a value shapes a specific interpretation patternbeing focused on the effectiveness of each action. And, as the dancer's only means of existing and succeeding in this world is the body, they transform it to fit the requirements of the social world. In this way, through the dancer's actions and interactions with others, the meaning ascribed to the body becomes flesh.

\section{The Perception of the Body}

From the age of six or seven, children who practice ballroom dancing are taught a specific perspective from which to perceive and treat their bodies. In the process of acquiring bodily knowledge through interactions with a trainer or dancing partner, a dancer learns how to communicate with their body, differentiate its various states (e.g., fatigue) and sensations (different kinds of pain, see also: Byczkowska-Owczarek 2013). The definition of those states is usually provided by trainers, who become significant others through the process of a dancing career. The way they transmit the culturally specific perspective of the body is illustrated below, by a young female dancer describing the issue of breaking one's bodily limits: 
In my case, this [breaking the limits-DBO] took place basically during one training session when my trainer approached me. He caught me by the face, and, I mean, he touched me so gently, so passionately, and, as if he wanted to kiss me. I was very scared because I was a little girl [laughs], but since then, I've been able to do basically anything, with every partner, to dance what you need; these are actually difficult matters... but simple recipes. [interview with a female ballroom dancer, 18 years of age]

Such kinds of interactions, based on mutual trust, construct in the dancers' minds a specific image of their bodies. Young dancers start looking at their bodies through their trainers' (and judges') eyes. They begin to perceive them as being excluded from general cultural rules, especially in the context of a ballroom dancing training session or contest. Ballroom dancers become their reference group along with the change of their social identity-that of a ballroom dancer. As Everett Hughes (1997) states, the identities depend on the activities. The more frequent and more prolonged training sessions, the stronger the dancer's identity. Also, the sessions are time-consuming, so the individual has a smaller chance to develop alternative identities, for example, of a footballer, ice-skater.

The specific perception of the body is not limited to their bodies. Along with the socialization in the social world at hand, ballroom dancers start interpreting all dancers' bodies in terms of effectiveness, especially that of their dancing partners. The bodily limits and the concept of intimacy are perceived through the prism of effectiveness. Social actors act towards the body according to such a definition. One of the interviewees, a thirteen-year-old male dancer, described the way he treats his partner's body. When he is to perform some passionate movement, for example, to grab his partner's hip, he sees such a gesture in a purely task-oriented way. He does it because he knows that their result in the tournament depends on it. Although in the beginning, it may be difficult and require breaking their and partner's bodily limits, the trainers provide definitions of situation normalizing the gestures as not intimate, but effective. The close and seemingly erotic contact between the partners is perceived as an element of the judges' assessment.

In diverse situations of such kind (e.g., wearing revealing dresses, erotic movements, sexy glances), through interactions with trainers, dancing partners, other dancers, and parents, a dancer learns to perceive their body effectively. Also, through their experiences during training sessions and hours spent working on and with the body, the dancer learns what meanings internal bodily sensations may have. Older dancers and trainers usually provide the definitions of such states. Just like in Howard Becker's classical "Becoming a Marihuana User" (1953), others teach an individual how to interpret what is going on with their body. The kinds of pain (injury or muscle development?), fatigue (injury risking or toughening?), emotions (personal or imposed by the dance genre?) are subjected to the interpretation provided by (significant) others.

As a result of the processes of interactions, the dancer internalizes three coexisting ways of perceiving their (and others') bodies. They act differently towards the same object-the body-depending on the definition of the situation: training session, contest, training camp. A male ballroom dancer, judge and trainer, describes such situatedness:

Dancer: You have to feel your own body and sometimes listen to your own body. 
Researcher: Listen to the body, or should the body listen to us?

Dancer: If I train, the body should listen to me, but if I feel that it hurts me so much that I cannot cope, then I cannot be stupid enough to try to do something against my body...because the body can rebel, say "enough," break something, and not cooperate with me anymore. That's exactly what this is.

They may appear separately; however, a dancer may perceive their body in two coexisting ways at the same time, depending on the actions undertaken through the body. These types are:

1. A tool, thanks to which they may achieve a higher position in the social subworld of ballroom dancing, and develop and construct their identity. As a thirty-year-old female dancer declares: "for me, my body is a way of expressing things."

2. A material changed according to a specific trend, set by the dance genre, usually embodied by famous dancers and the dance teacher. This category mainly refers to appearance, but is not limited to it. The dancer learns to look at their body through the eyes of a generalized other, comparing their body (shape, skin color, hairdo, etc.) with the internalized image of a perfect looking dancer.

Two perspectives mentioned above may be categorized as the Straussian "the body as object" (1993:119). It is acted towards by other actors: individuals, groups, organizations. Moreover, as presented in the example, a social actor may also act towards their body.

3. A partner, whom they must take into consideration when making plans and who applies its logic, sometimes different from the dancer's will. Experienced dancers usually interpret the signals from their bodies in terms of their meaning for current and future actions and plans. The dancer interprets a specific sensation, and future actions depend on it. One of the female dancers describes how this process may take place:

And the worst thing for my body is my mind when it knows that I'm a workaholic, because it has already got used to that, and it knows that the body starts to go flat, doesn't it? That it is already overtired, that it has too many toxins, that it needs to rest...Then my body invents a forty-degree fever. I'm unconscious, and the doctors don't know what's going on, maybe an inflammation, maybe something. And with my body, it is simply like this, that it invents a forty-degree fever, and that forty degrees knock me down. Because, if it gives me a thirty-eight-degree fever, I will go to work anyway. I will take an anti-fever injection and go anyway 'cause I'm not normal in this case...I think it is a lack of respect, isn't it? For the body.

Such a way of perceiving one's body may be characterized by a Straussian term "the body as agent." As humans always act through their bodies, consciously or unconsciously, the body becomes particularly evident when it loses its normal abilities. This type of body limits an individual in their everyday actions and interactions, which results in redefining the meaning of the body, and usually also individual identity. ${ }^{5}$ The body becomes a silent actor with whom the dancer must negotiate (Strauss 1993:110, 117).

${ }^{5}$ For example, in Murderball, a documentary showing the life of disabled American rugby players, we can see a change in the self-identity of an individual as a result of losing former physical abilities and then acquiring new ones. 
Communicating the meanings of the body by a dance teacher takes place more directly when handling the body as a material and a tool. A dancer receives a clear definition if they performed a movement properly or not, or if their look is "Latin enough" to dance the cha-cha-cha in a contest. In the case of treating one's body as an interactional partner, the communication is more indirect, referring to more general hints of how to interpret certain sensations from the body. The relationship between the dancer and their body as a partner is more of an individual, intimate nature, and is developed at higher levels of a dancer's career. It requires more significant experience in recognizing the signals from the body. Interpretation of information coming from the dancer's body is due to a long process of interaction with one's body.

Such a way of negotiating with the body or interacting with it is characteristic not only of dancers. People undergoing psychotherapy, or the so-called self-study, in which the subject, oneself, becomes the object of the study, also use their bodies as one of the ways to discover their personality and solve problems. They do this through contact with the body, which is perceived as being autonomous, to some extent (Lussier-Ley 2010).

\section{Dancer's Body in Two Processes}

The course of a dancing career is influenced by two processes, which consequently and intentionally lead a dancer to gain the best possible results in a contest. The body is both the means and an effect of the processes at hand. The first process is supposed to satisfy the expectations of physical strength, stamina, and technical skillfulness. Such values are brought to life (and flesh) through in- teractions with a trainer and actions towards one's body. This process is called sharpening the tool. The term refers to the actions of a dancer and their partner aimed at physical preparation for the performance. They include frequent training, following a specific diet, muscle building exercises, et cetera. Such actions not only affect the way one perceives their body, but they also shape it directly, through muscles and bones. If the dancer wants to exist in this social subworld, they must adjust their body to the image internalized by those who are in power-the judges. The body must work in a certain way. Therefore, the social actor must perform specific actions towards it. They must develop bodily skills, which make the body exercise similarly to the ideal. That is how, in ballroom dance, some general values become flesh-through internalization of the notion of a "proper" movement, skill, ability.

The second process refers to a dancer's practices aimed at preparing their appearance. They are called polishing the tool. When a ballroom dancer performs at a contest, their body must be adequately prepared by, for example, tanning, makeup, hairstyle, nail work, teeth whitening, et cetera. Dance, as a genre of art, ${ }^{6}$ needs an aesthetic effect, which is also judged during a contest. Such activities have a significant influence on the way a dancer perceives their body, also in terms of gender roles. The latter are defined in a specific way in this social subworld. The looks and precisely ascribed characteristics of both genders must be performed during the contest and are a part of the judges' assessment.

\footnotetext{
${ }^{6}$ The question of whether ballroom dance is more a sport or art is addressed in my article "Performing on the Boundary of Art and Sport: The Case of Competitive Ballroom Dancers" (Byczkowska-Owczarek 2019).
} 
Both practices, sharpening and polishing the tool, incorporate the specificity of ballroom dancing in a dancer's body. The culture, values, norms, social control, and individual and group identities transmitted through interactions with trainers, as significant others, and other dancers become embodied in their muscles, bones, hair, skin.

\section{Conclusions}

In the article, I aimed at presenting the processual link between symbolic interactions and the human body. From the very beginning of our life, we interact with individual and group social actors. No action is possible without the body (Strauss 1993:109). Such interactions shape the process of socialization, our identity, social roles, which we direct towards ours and others' bodies (Plummer 2012:77). In the process, social phenomena are incorporated in the most literal, physical sense. The intermediation of culture and the human body becomes evident when we study people's experiences-take a closer look and try to understand their actions. SI, a perspective that places the individual experience first, is a useful and valuable theory in sociological research on the human body.

Ken Plummer (2012:77) argues that the human body has multiple meanings and is shaped by the number of social roles, selves, and relationships with significant others we are engaged in. SI is a "down-to-earth approach" (Blumer 1969 as cited in Plummer 2012)-its theoretical assumptions demand that we get as close as possible to actual bodily experiences in their natural worlds. The researched body must be grounded in the cultural, group, political, or ethical context. There is no "objective," "average," or "constant" body in social reality. Bodies, continuously emerging from social interactions, are available only for their owners' experiences. As Strauss claims (1993), when we consciously focus on the body, we study the social aspects and processes of the body, which become visible through actions and interactions. The processes include various aspects or parts of the body, its diverse actions, and the body may be seen as an object and as an agent.

Therefore, to study their actions, a researcher is always dependent on the bearer of the body. Such a situation requires challenging the methodology and research methods, which enable us to touch the experience of the body, especially its unconscious, incorporated knowledge (Jakubowska 2017). Additionally, as a physical entity, it is always analyzed by a researcher as an embodied actor, with their feelings, emotions, sensations, social roles, and experiences. It may be both advantageous and disadvantageous when conducting research (Byczkowska-Owczarek and Jakubowska 2018).

When it comes to the essential concept of SI-identity-it is considered to be a result of interacting with others (Berger and Luckmann 1983), but also undertaken actions (Hughes 1997:393). The time spent on various bodily activities (dancing, yoga, work, medical operation, conducting an orchestra) builds individual and group identities (including bodily identities) based on these actions. It is not only an activity that constructs a person's identity, but also a lack of one. People who had undergone severe physical changes due to illness or accident deal with a deconstructed identity, as they cannot use their bodies the way they used to (see also: Manderson 2011:30, 67). Persons who are, in some way, perceived as undergoing a physical crisis are stigmatized (as understood by Erving Goffman 2005), so they do not define themselves with the 
normal rules of interaction. Strangers approach and ask about the most intimate details of their disabilities, whereas loose friends avoid contact. In both cases, the status of normals has been suspended and, consequently, different rules of interaction apply. A person who is ill is forced to create a new identity in interactions with others, learn new rules of interaction, and take on the role of a person with stigma. A vital element of those new interactions is a "flattened" interactional identity. For disabled partners, the disability is in the foreground, which reduces the importance of other aspects of their identity (Manderson 2011:88). It involves entering another, a new reality, and the need to face new, interactive challenges (Goffman 2005). Such an individual needs to learn to interact with their new "set" of physical features and capabilities. They may also need to incorporate technology into their bodies, to replace the lost capabilities (e.g., wheelchair) or the bodies of others (people or animals) who help them (Strauss 1993:110). The definition of "my body" is, in this case, reconstructed.

The way our bodies are transformed is dependent on social processes on several levels. The first one is a cultural dimension, which includes the media (as described in Goffman's Gender Advertisements 1979), specific subcultures of social worlds, and subworlds. Socially constructed ideas of beauty, health, femininity, or masculinity influence the way we act towards our bodies. The looking-glass self is highly sensitive to all the interactional information concerning our bodies. ${ }^{7}$ What is more,

\footnotetext{
${ }_{7}^{7}$ The cultural changes concerning norms of beauty and health may take a destructive form of, for example, anorexia, bulimia, or orthorexia nervosa. Such diseases do not only change the physical body, but may lead to severe dysfunctions or death, which shows the strength of social influence concerning the human body.
}

the body is our primary tool of being in the world and of completing tasks connected with our social roles. The individuals develop their bodies in a gym, at a beautician, tattoo artist, along with the expectations of the generalized other.

Our bodies are also socially constructed on a group level, as bodily conduct differs significantly not only between national or regional cultures, but also in different social groups and communities. Each role-making requires differentiated bodywork, different perspectives of perceiving one's body, as social groups need a "social body" to perform various responsibilities. The physical skills concerning any social role, the process of doing work show the bodily character of socially constructed knowledge and how theoretical knowledge is acted out in the practice of work (see also: Hughes 1958; 1971; 1997). Since interpretation underpins every action and interaction, the body becomes symbolically meaningful. Bodily processes, parts, movements, systems, gestures are interpreted by the social actor or by others and acquire meaning (Strauss 1993:120). To use the body properly as a tool of role-making, we need to learn how to use and incorporate technologies specific to our social roles and the groups we participate in. The processes mentioned above are realized in interactions between humans, but also between humans and objects, such as photos, food, technical equipment. All the cultural and group norms concerning the human body are brought to life through symbolic interaction, including emotions, persuasion, exchange, identity construction. Based on such interactions, humans direct particular actions towards their bodies and construct them socially (Strauss 1993). There is no interaction without body and no body / nobody without interaction. 


\section{References}

Becker, Howard S. 1953. "Becoming a Marihuana User." The American Journal of Sociology 59(3):235-242.

Becker, Howard S. et al. 1961. Boys in White. Student Culture in Medical School. Chicago: University of Chicago Press.

Berger, Peter L. and Thomas Luckmann. 1983. Społeczne tworzenie rzeczywistości [Social Construction of Reality]. Warsaw: Państwowy Instytut Wydawniczy.

Blumer, Herbert. 2007. Interakcjonizm symboliczny [Symbolic Interactionism]. Cracow: Zakład Wydawniczy Nomos.

Byczkowska, Dominika. 2009. “What Do We Study Studying Body? Researcher's Attempts to Embodiment Research." Qualitative Sociology Review 5(3):100-112.

Byczkowska, Dominika. 2012. Ciało w tańcu. Analiza socjologiczna [Body in Dance. Sociological Analysis]. Lodz: Wydawnictwo UŁ.

Byczkowska-Owczarek, Dominika. 2013. “Społeczne oblicza bólu - informacja, przyjemność, przekleństwo. Kulturowe, grupowe i interakcyjne uwarunkowania odczuwania doznań bólowych [Social Faces of Pain-Information, Pleasure, Curse. Cultural, Group, and Interactional Conditions of Pain Experience]." Studia Socjologiczne 4(211):165-192.

Byczkowska-Owczarek, Dominika. 2018. "Sociology of the Body-Research Practice in Poland." Qualitative Sociology Review 14(2):12-28.

Byczkowska-Owczarek, Dominika. 2019. "Performing on the Boundary of Art and Sport: The Case of Competitive Ballroom Dancers." Sociologický časopis / Czech Sociological Review 55(3):369-392.

Byczkowska-Owczarek, Dominika and Honorata Jakubowska. 2018. "Sociology of the Body-Teaching Embodied Approach through Autoethnography." Qualitative Sociology Review 14(2):152-164.

Charmaz, Kathy. 2006. Constructing Grounded Theory. A Practical Guide through Qualitative Analysis. London, New Delhi: Sage Publications.

Charmaz, Kathy. 2014. Constructing Grounded Theory. Los Angeles, London, New Delhi, Singapore, Washington: Sage.
Clarke, Adele. 1990. “A Social Worlds Research Adventure. The Case of Reproductive Science." Pp. 15-42 in Theories of Science in Society, edited by S. E. Cozzens and T. F. Gieryn. Bloomington, Indianapolis: Indiana University Press.

Corbin, Juliet and Anselm L. Strauss. 2007. Basics of Qualitative Research. Techniques and Procedures for Developing Grounded Theory. London: Sage.

Denzin, Norman. 1972. “The Research Act.” Pp. 76- 91 in Symbolic Interaction. A Reader in Social Psychology, edited by J. Manis and B. N. Meltzer. Boston, London, Sydney, Toronto: Allyn and Bacon.

Dwojnych, Anna and Katarzyna Kuczkowska-Golińska. 2018. "The Theater Plays the Body. Replication of the Canon of Beauty among Young Actresses in the Theater." Qualitative Sociology Review 14(2):78-94.

Glaser, Barney. 1978. Theoretical Sensitivity. San Francisco: Sociology Press.

Glaser, Barney G. and Anselm L. Strauss. 1965. Awareness of Dying. Chicago: Aldine.

Glaser, Barney G. and Anselm L. Strauss. 1967. The Discovery of Grounded Theory: Strategies for Qualitative Research. Chicago: Aldine Publishing.

Goffman, Erving. 1959. The Presentation of Self in Everyday Life. Garden City, NY. Doubleday.

Goffman, Erving. 1963. Stigma. Notes on the Management of Spoiled Identity. New York, London, Toronto: Simon and Schuster.

Goffman, Erving. 1979. Gender Advertisements. New York: Harper Torchbooks.

Goffman, Erving. 2005. Interaction Ritual: Essays in Face to Face Behavior. New Brunswick, NJ: Transaction Publishers.

Hughes, Everett C. 1958. Men and Their Work. Glencoe, IL: Free Press.

Hughes, Everett C. 1971. The Sociological Eye. Selected Papers. Chicago: Aldine. 
Hughes, Everett E. 1997. “Careers." Qualitative Sociology 20(3):389-397.

Jakubowska, Honorata. 2012. “Ciało jako przedmiot badań socjologicznych - dylematy, pominięcia, możliwości [Body in Sociological Research-Questions, Omissions, Prospects]." Przeglad Socjologii Jakościowej 8(2):12-31.

Jakubowska, Honorata. 2017. Skill Transmission, Sport and Tacit Knowledge. A Sociological Perspective. Abington: Routledge.

Jakubowska, Honorata and Dominika Byczkowska-Owczarek. 2018. "Girls in Football, Boys in Dance. Stereotypization Processes in Socialization of Young Sportsmen and Sportswomen." Qualitative Sociology Review 14(2):12-28.

Kacperczyk, Anna. 2005. “Zastosowanie koncepcji społecznych światów w badaniach empirycznych [Application of Social Worlds Theory in Empirical Research]." Pp. 169-191 in Konstruowanie jaźni i społeczeństwa. Europejskie warianty symbolicznego interakcjonizmu [Constructing the Self and Society. European Variants of Symbolic Interactionism], edited by E. Hałas and K. T. Konecki. Warsaw: Scholar.

Kacperczyk, Anna. 2016. Społeczne światy. Teoria-empiria-metody badań. Na przykładzie społecznego świata wspinaczki [Social Worlds. Theory-Methods-Empirical Research. An Example of the Social World of Climbing]. Lodz: Wydawnictwo Uniwersytetu Łódzkiego.

Konecki, Krzysztof T. 2000. Studia z metodologii badań jakościowych. Teoria ugruntowana [Studies in Qualitative Research Methodology. Grounded Theory]. Warsaw: Wydawnictwo Naukowe PWN.

Konecki, Krzysztof T. 2005. “Problem interakcji symbolicznej a konstruowanie jaźni [The Issue of Symbolic Interaction and the Construction of the Self]." Pp. 40-58 in Konstruowanie jaźni $i$ społeczeństwa. Europejskie warianty symbolicznego interakcjonizmu [Constructing the Self and Society. European Variants of Symbolic Interactionism], edited by E. Hałas and K. T. Konecki. Warsaw: Scholar.

Konecki, Krzysztof T. 2008. "Touching and Gesture Exchange as an Element of Emotional Bond Construction. Application of Visual Sociology in the Research on Interaction between Humans and Animals." Forum Qualitative Sozialforschung / Forum: Qualitative Social Research 9(3):Art. 33.

Konecki, Krzysztof T. 2016. Is the Body the Temple of the Soul? Modern Yoga Practice as a Psychosocial Phenomenon. Cracow: Jagiellonian University Press.
Kowal, Katarzyna. 2012. “Doświadczanie własnej cielesności przez biorców kończyny - socjologiczne studium zrekonstruowanego ciała [Limb Recipients' Experience of Their Own Corporeality-Sociological Study of Reconstructed Body]." Przeglad Socjologii Jakościowej 8(2):152-199.

Lussier-Ley, Chantale. 2010. “Dialoguing with the Body: A SelfStudy in Relational Pedagogy through Embodiment and the Therapeutic Relationship." The Qualitative Report 15(1):196-214.

Manderson, Lenore. 2011. Surface Tensions. Surgery, Bodily Boundaries and the Social Self. Walnut Creek, CA: Left Coast Press.

Merleau-Ponty, Maurice. 1965. Phenomenology of Perception. London: Routledge \& Kegan Paul.

Nelson, E. D. (Adie). 2001. "The Things That Dreams Are Made On: Dreamwork and the Socialization of 'Stage Mothers.'" Qualitative Sociology 24(4):439-458.

Niedbalski, Jakub. 2015. “Przemiany percepcji własnego ciała przez osoby z niepełnosprawnością fizyczną uprawiające sport [Transformation in the Perception of Their Own Bodies among Physically Disabled Persons Practicing Sport]." Studia Socjologiczne 3:221-240.

Oktay, Julianne S. 2012. Grounded Theory. Oxford: Oxford University Press.

Plummer, Ken. 2012. “My Multiple Sick Bodies: Symbolic Interactionism, Autoethnography and Embodiment." Pp. 75-93 in Routledge Handbook of Body Studies, edited by B. S. Turner. New York: Routledge.

Rambo Ronai, Carol. 1992. "Managing Aging in Young Adulthood. The Aging Table Dancer." Journal of Ageing Studies 6(4):307-317.

Ślęzak, Izabela. 2012. "Alcohol Use as a Work Factor among Female Sex Workers in Escort Agencies." Alcoholism and Drug Addiction 25(4):33-52.

Ślęzak, Izabela. 2018. "A Present and a Non-Present Body-Experiencing the Body by Female Sex Workers in Commercial Sexual Relations." Qualitative Sociology Review 14(2):30-50.

Strauss, Anselm L. 1978. "A Social World Perspective." Studies in Symbolic Interaction 1:119-128.

Strauss, Anselm L. 1982. "Social World and Legitimation Processes." Studies in Symbolic Interaction 4:171-190. 
Strauss, Anselm L. 1987. Qualitative Analysis for Social Sciences. New York, Cambridge: Cambridge University Press.

Strauss, Anselm L. 1993. Continual Permutations of Action. New York: Transaction Publishers.

Strauss, Anselm L. and Juliet Corbin. 1990. Basics of Qualitative Research. Grounded Theory Procedures and Techniques. Newbury Park, London, New Delhi: Sage Publications.

Strauss Anselm L. et al. 1997. Social Organization of Medical Work. New Brunswick, London: Transaction Publishers.

Turner, Bryan S. 1984. The Body and Society: Explorations in Social Theory. Oxford, New York: B. Blackwell.

Turner, Bryan S. and Steven P. Wainwright. 2003. "Corps de Ballet: The Case of Injured Ballet Dancer." Sociology of Health and Illness 25(4):269-288.

Vaskul, Dennis E. and Phillip Vannini. 2006. Body/Embodiment: Symbolic Interaction and the Sociology of the Body. London, New York: Routledge.
Wacquant, Loïc. 2004. Body and Soul: Notebooks of an Apprentice Boxer. New York: Oxford University Press.

Wainwright, Steven P. and Bryan S. Turner. 2004. “Epiphanies of Embodiment: Injury, Identity and the Balletic Body." Qualitative Research 4(3):311-337.

Wojciechowska, Magdalena. 2015a. "Men Who Like Using and Abusing Women: The Perspective of Clients on Escort Agency Workers." Studies in Symbolic Interaction 45:1-21.

Wojciechowska, Magdalena. 2015b. “O działaniu w ramach konceptualnej niewidzialności. Przykład badań nad macierzyństwem jednopłciowym w doświadczeniu matek niebiologicznych" [Acting within the Context of Conceptual Invisibility. How Non-Biological Lesbian Mothers Experience Motherhood]." Przeglad Socjologii Jakościowej 11(4):114-145.

Wojciechowska, Magdalena. 2020. Dwie matki jednego dziecka [Two Mothers of One Child]. Lodz: Wydawnictwo Uniwersytetu Łódzkiego.

\section{Citation}

Byczkowska-Owczarek, Dominika. 2020. "Body and Social Interaction-The Case of Dance. Symbolic Interactionist Perspective." Qualitative Sociology Review 16(4):164-179. Retrieved Month, Year (http://www.qualitativesociologyreview.org/ENG/archive_eng.php). DOI: http://dx.doi.org/10.18778/1733-8077.16.4.10 